\title{
Z Kuşağının Dindarlık Eğilimleri ${ }^{1}$
}

\author{
Sena $G \ddot{O} K C E^{2}, \dot{I}$ shak TEKIN ${ }^{3}$
}

\section{$\ddot{\mathbf{O} z}$}

$\mathrm{Bu}$ çalışma Kuşak Teorisi merkezinde Z kuşağının dindarlık eğilimlerini ortaya koymayı amaçlamaktır. Bu amaç doğrultusunda çalışmada Türkiye'nin farklı şehirlerinde, farklı sosyo-ekonomik düzeye sahip Z kuşağından kişilerle görüşmeler yapılmış ve onların dindarlık eğilimleri analiz edilmiştir. Araştırma verilerinin toplanmasında yarı yapılandırılmış görüşme tekniklerinden yararlanılmıştır. Çalışma grubunun oluşturulmasında ise amaçlı örnekleme yöntemlerinden ölçüt örnekleme tercih edilmiştir. Araştırmada; katılımcıların dinin bireysel boyutuna daha fazla vurgu yaptıkları, onu daha çok kendilerine fayda sağlayan, ayrıcalık tanıyan veya kendilerini iyi hissetmelerine yardım eden bir sebep olarak anlamlandırdıkları; açıklamalarında dinin ibadet boyutunun yanında etki, bilgi, ahlak gibi boyutlarına da işaret ettikleri görülmüştür. Ayrıca katılımcıların hayatında dinin etkisinin daha az görüldüğü, ibadethaneye gitme sıklığının az olduğu ve düzenli bir ibadethane rutinlerinin olmadığı, toplu dini ibadetlere katılmayı tercih etmedikleri, kendilerini dindar olarak görmedikleri, ibadetler sonrası olumlu duygular hissettikleri, dini bilgi edinmeyi önemsedikleri, daha çok internet üzerinden araştırma yapmayı tercih ettikleri ve arkadaş seçimlerinde arkadaşlarının dini inanç ve yaşantılarına dikkat etmedikleri sonuçlarına ulaşılmıştır.

\section{Anahtar Kelimeler}

Din Psikolojisi • Dindarlık • Gençlik • Kuşak Teorisi • Z Kuşağ 1

\footnotetext{
${ }^{1} \mathrm{Bu}$ çalışma Sena Gökçe tarafından Dr. Öğr. Üyesi İshak TEKİN danışmanlığında hazırlanan "Kuşaklara Göre Dindarlık Eğilimleri: Y ve Z Kuşaklarının Dindarlık Eğilimleri Üzerine Bir İnceleme” başlıklı yüksek lisans tezinden üretilmiştir.

${ }^{2}$ Bilim Uzmanı, Eskişehir Osmangazi Üniversitesi Sosyal Bilimler Enstitüsü, Din Eğitimi Bilim Dalı, gokce.sena12@gmail.com, ORCID: 0000-0001-6852-4108

${ }^{3}$ Dr. Öğr. Üyesi, Eskişehir Osmangazi Üniversitesi İlahiyat Fakültesi, Din Eğitimi Anabilim Dalı, ishaktekin05@gmail.com, ORCID: 00000002-3850-5691
} 


\title{
The Religiosity Trends of Generation Z
}

\author{
Sena GÖKÇE, İshak TEKINN
}

\begin{abstract}
The study aims to determine the characteristics of religious tendencies of Generation $\mathrm{Z}$ in the focus of Generation Theory. For this purpose, in the study it was analyzed that people from Generation $\mathrm{Z}$ with different socio-economic levels and living in different cities of Turkey were interviewed and their religious tendencies were determined. In this study, semi-structured interview methods from qualitative research methods were used to collect data. In the determining of the sample group, criterion sampling was preferred, which it is from one of the purposive sampling methods. Participants pay more importance to the external meanings of religion. They understand religion as limited to a few specific dimensions. Participants mostly define religion in terms of the benefits it provides to them. The frequency of going to places of worship is lower for Generation Z. The participants do not have a routine visit to worship places. They do not consider themselves religious and feel positive emotions after the prayers. The participants care about obtaining religious knowledge and mostly research on the internet. Religion does not affect the choice of friends of Generation Z.
\end{abstract}

\section{Keywords}

Psychology of Religion $\bullet$ Religiosity $\bullet$ Youth $\bullet$ Generation Theory $\bullet$ Generation Z

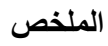

الميول الدينية للجيل

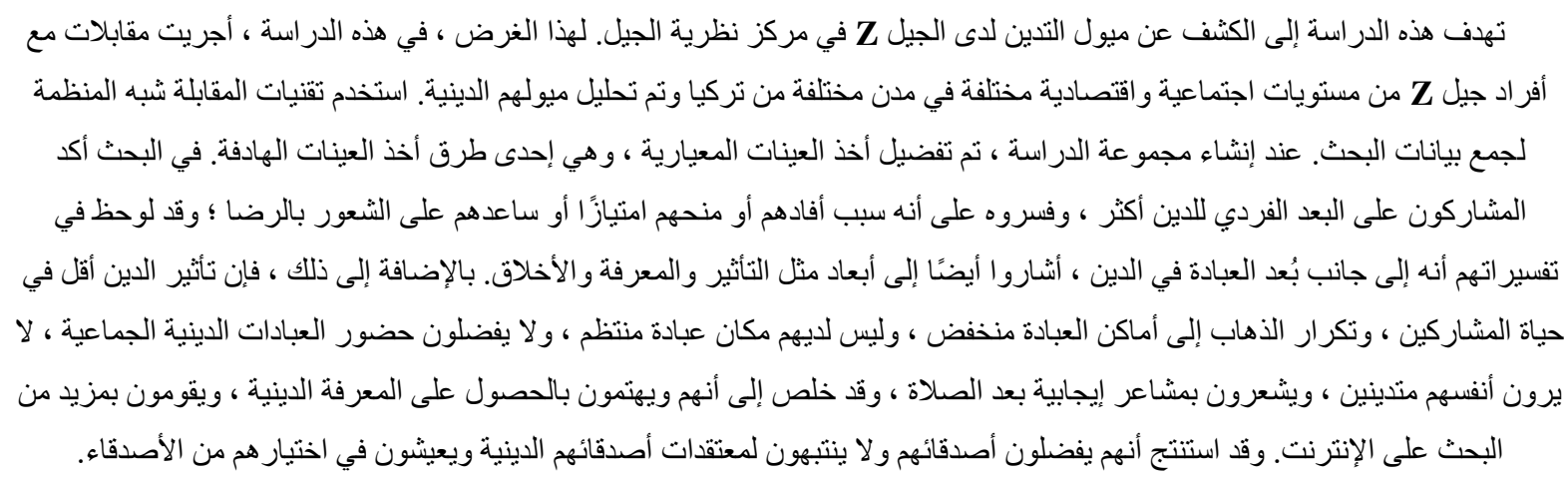


Bir toplumun varlığını devam ettirebilmesi ve kültürel aktarımı sağlayabilmesi bakımından gençler önemli bir yere sahiptir. Buna karşın gençlerle yetişkinler arasında din ve değerler açısından sürekli bir gerilim hattının olduğu da toplumdaki hemen herkes tarafından gözlemlenmektedir. Bu çatışma durumunun ortaya çıkmasında her iki tarafın rolü olsa da genelde sorunun merkezinde gençler konumlandırılmaktadır. Zira 18-24 yaş arasını kapsayan gençlik dönemi, değerlere ve inanca ilişkin sorgulamalar ile inanç krizlerinin ortaya çıkabildiği, toplumca benimsenen genel ilke ve uygulamaların sorgulanabildiği bir geçiş dönemidir. Kimlik ve kişiliğin oluştuğu, önemli krizlerin yaşandığı bu dönemde yetişkinlerin gençlerle sağlıklı bir iletişim kurması gerekliliği ortadadır. Bu durum, gençlik dönemi çalışmalarını önemli hale getirmektedir. Gençlik çalışmalarıyla ilgili olarak kuşak kavramı ve bu kavram çerçevesinde şekillenen Kuşak Teorisinin konuya ilişkin yeni açılımlar getirebileceği düşünülmektedir.

Kuşak kavramı Türk Dil Kurumu [TDK] Sözlüğü’nün (2020) tanımına göre; yaklaşık olarak aynı yıllarda doğmuş, aynı çağın şartlarını dolayısıyla birbirine benzer sıkıntıları, kaderleri paylaşmış, benzer ödevlerle yükümlü kişiler topluluğudur. Aynı kuşağın bireyleri, kendilerine has ortak bir tarih ile şekillenmiş ortak kişilik ve davranış formlarına sahiptir (Sarığlu, 2018, s. 25). Her kuşak kendi yaşadığı toplumdan etkilenirken aynı zamanda yaşadığı toplumu etkileme ve dönüştürme özelliğine de sahiptir. Kuşak kavramı ilk olarak Karl Mannheim tarafından 1928 yılında kullanılmış (Kuran, 2020, s. 25), Strauss ve Howe (1991) tarafından ise bir teori olarak nihai haline getirilmiştir. Kuşak teorisine göre kuşaklar; tarihte yaşanan önemli toplumsal olaylar, yaşanmışlıklar, değişen anlayış, dünya görüşleri ve değerler çerçevesinde sınıflandırılmaktadır. Kuşak isim ve özellikleri ülkelere göre birbiri ile benzer olsa da başlangıç ve bitiş dönemleri ülke ve kültürlere göre farklılık gösterebilmektedir. Buna göre Türkiye'de kuşaklar, 1925-1945 arası Sessiz Kuşak, 1946-1964 arası Patlama Kuşağı, 1965-1979 arası X Kuşağı, 1980-1999 arası Y Kuşağı, 2000 ve sonrasında doğanlar ise Z Kuşağı olarak kabul edilmektedir. Ayrıca 2015 yılından sonra doğanlar Alfa Kuşağı; 2025 yılı sonrası doğacak olanlar ise Beta Kuşağı olarak isimlendirilmektedir (İnce, 2018, s. 19). Türkiye nüfusunun yaklaşık yüzde otuzunu oluşturan (Kuran, 2020, s. 132) ve farklı ülkelerde “İ Kuşağı”, “@ Kuşağı” gibi isimlerle anılan Z kuşağı, ülkemizde "Kristal Nesil”" olarak da adlandırılmaktadır. Bunun yanında Z kuşağı aşırı bireyselleşme ve sonrasında yaşanan yalnızlık hissinden dolayı "Sessiz Kuşak” ya da "derin duygusal” olarak da adlandırılmıştır (Sarığlu, 2018, s. 25; Özkoç ve Bayrakdaroğlu, 2017, s. 87).

Z kuşağı bireylerinin davranışları, tutumları, din ve maneviyat yönelimleri, sosyal ve politik düşünceleri önceki nesillere göre oldukça farklı gözükmektedir. Z kuşağını diğer kuşaklardan ayıran en büyük farklılık, akıllı telefonların yaygınlaşması ile birlikte, onların zaman geçirme biçimlerinde ortaya çıkmıştır. Bu farklılık özellikle son y1llarda artan kayg1, depresyon ve intihar eğilimlerinde kendisini göstermektedir (Twenge, 2018, s. 23-26). Büyük teknolojik yeniliklerin içine doğan Z kuşağı çocuklarının teknolojik aletlerin kullanımında oldukça yetenekli oldukları ve telefonla mesajlaşmak, internette dolaşmak, online oyunlar oynamak gibi vakitlerinin çoğunu bu mecralar üzerinde geçirdikleri görülmektedir (Türk, 2013, s. 21). Buna göre Z kuşağ1 gençleri hayatlarını çevrimiçi ve herkesin gözü önünde yaşayan bir kuşak olarak karşımıza çıkmaktadır (Twenge, 2018, s. 137). Z kuşağı bireylerinin genel özellikleri arasında şunlar sayılabilir (Özkoç ve Bayrakdaroğlu, 2017, s. 12): Üretme konusunda oldukça becerikli, içinde doğdukları zamanın da etkisiyle görselliği seven, yaşamlarını 
çoğunlukla pragmatik sürdüren bireylerdir; bu kuşağın çocukları çevre olaylarına ve çevrenin korunmasına karşı oldukça hassastır ve bununla beraber adalet ve eşitlik konularında da dikkatlidir. Ayrıca $Z$ kuşağı teknolojiye bağımlı, aceleci, yaratıcı, anlık tüketen bireylerdir.

Tweng'e (2018, s. 70) göre ailelerin koruyucu tutumlarının bir sonucu olarak Z kuşağının çocukluktan ergenliğe geçişleri ve yetişkin olmaları önceki kuşaklara göre daha yavaş gerçekleşmektedir. Tweng'in araştırmasında Amerikan toplumundaki Z Kuşağı (i-Nesli); Bebek Patlaması kuşağı ve X kuşağı kadar dindar değildir. Çalışma hem kamusal alanda hem de özel hayatlarında $Z$ neslinden dindar kişilerin sayısının gün geçtikçe azaldığını göstermektedir (Twenge, 2018, s. 172-175). Amerikan kültüründe yetişen gençler özelinde yapılan bu çalışmanın Türkiye'deki Z kuşağı neslinin dindarlık eğilimleri bakımından fikir verebileceği söylenebilir. Kuşak teorisi ve $Z$ kuşağı ile ilgili ifade edilen bu hususlar, $Z$ kuşağının din ve değerlere ilişsin anlayış ve tutumlarında farklılaşmanın olduğunu göstermektedir.

Türkiye'de de gençlik problemlerini ele almak amacıyla çeşitli gençlik araştırmaları yapılmıştır. Son dönemde ülkemizdeki gençlerle ilgili yayımlanan çalışmalara bakıldığında; gençlerin siyasetle çok fazla ilgili olmadıkları, toplumsal kabuller ve kişisel/cinsel alan içerisinde düşünülebilecek bazı tercihler açısından daha fazla özgürlük ve özerklik talep ettikleri, inanç ve değer tercihlerine müdahale edilmemesini ve sayg1 duyulmasını bekledikleri, hayatlarını bağımsız ve kendi tercihlerine göre sürdürmeyi istedikleri, yurtdışında yaşamayı ve eğitimlerini orada devam ettirmeyi arzuladıkları, daha fazla internet ve sosyal medya kullandıkları vb. birçok husus göze çarpmaktadır (Sosyal Ekonomik ve Kültürel Araştırmalar Merkezi [SEKAM], 2013; Akyüz, 2014; Karsl1, 2021; Topçuoğlu ve Arslan, 2021).

Ayrıca gençlerin din ve değer algılarıyla ilgili yazılan tezler ve makaleler de önemli sonuçlar ortaya koymaktadır. $Z$ kuşağında yer alan ortaöğretim öğrencilerinin dindarlık düzeyleri ve ahlaki çözülme durumları arasındaki ilişkinin incelendiği çalışmada, ortaöğretim düzeyindeki öğrencilerde ahlaki çözülme düzeyi ile dindarlık eğilimi arasında anlamlı bir ilişki olduğu sonucuna ulaşılmıştır. Çalışmada dindarlık ölçeğinin alt boyutlarında yüksek puanlar alan öğrencilerin yüksek ahlaki çözülme düzeyi sergiledikleri görülmüştür (Çetin, 2019, s. 56). Lise gençliğinin din ve sekülerleşmeye ilişkin algıları üzerine yapılan bir çalışma, lise öğrencilerinin dini inanç konusunda sekülerleşmeye firsat vermeyecek şekilde Allah inancına sahip oldukları sonucuna ulaşmıştır. Bunun yanı sıra çalışmada öğrencilerin sosyal hayatlarında dinin etkisinin, inançlarıyla aynı oranda olmadığ tespit edilmiştir. Çalışmada dinin ibadet boyutu konusunda lise öğrencilerinin anne babalarına göre daha az ibadet ettikleri tespit edilmiştir (Şen, 2019, s. 150). Z Kuşağı ve Din başlıklı çalışmada, Z kuşağının din algılarını etkileyen etmenler, aile, okul ve arkadaşlar, teknoloji, sosyal mecralar ve bunların yanında özgürlük, kadın-erkek eşitliği ve eşcinsellik şeklinde sıralanmıştır. Araştırmada gençlerin kendilerini ailelerinden daha bilgili görmekle birlikte, dini pratik noktasında kendilerini ailelerinden daha zayıf olarak değerlendirdikleri görülmüştür (Aydın, 2020, s. 74). Z kuşağında deizm algısının incelendiği çalışmada, gençlerde deizm algısının belirli bir oranda var olduğu sonucuna ulaşılmıştır. Bu çalışmada Z kuşağından gençlerin Allah'a iman etmekle birlikte dinin ibadet boyutuna önem vermedikleri görülmüştür (Çalışkan, 2021, s. 153). Liseli gençlerin dindarlık eğilimi ve iyilik algısı arasındaki ilişki ile ilgili çalışmada; dindarlık tiplerinden iç güdümlü dindarlık ile iyilik algısı arasında pozitif yönde anlamlı, dış güdümlü dindarlık ile iyilik algısı arasında ise negatif yönde anlamlı ilişkinin olduğu tespit edilmiştir. Araştırmanın bulgularına göre katılımcıların \%60,7'sinin iç güdümlü dindarlık 
eğiliminde olduğu sonucuna varılmıştır (Bilge ve Kula, 2020, s. 236). Ergenlerde dindarlık, narsizm ve özgüven arasındaki ilişkinin incelendiği çalışmada, Z kuşağından liseli gençlerin dindarlık düzeyi ile narsizm eğilimi ve özgüven durumu arasında negatif yönlü anlamlı bir ilişki olduğu sonucuna ulaşılmıştır (Gürsu ve Özokudan, 2019, s. 451). Buraya kadar ifade edilen bütün bu çalışmalar, Z kuşağının din ve değer yönelimlerinde yetişkinlere göre önemli farklılıklar olduğu ve bu bağlamda söz konusu farkl1lıkların anlaşılmasına ve bunların nedenlerinin tespit edilebilmesine yönelik daha kapsamlı ve daha fazla araştırmaya bir ihtiyaç olduğuna işaret etmektedir.

Z kuşağının dindarlık eğilimlerinin nasıl olduğunu ve dinin hangi boyutlarına ne derece önem atfettiklerini ele almayı amaçlayan bu çalışma, kuşaklar arasında farklılaşan dini tercihler ve dindarlık algılamalarının daha iyi anlaşılabilmesine yardımcı olabilir. Bu noktadan hareketle bu çalışmanın temel problemi şöyle ortaya konulabilir: "Z kuşağının dindarlık eğilimleri nasıldır?” Bu temel problem çerçevesinde aşağıdaki alt problemler incelenecektir. Z kuşağındaki bireyler dini nasıl anlamlandırmaktadır? Z kuşağındaki bireylerin dinin farklı boyutlarına ilişkin yaklaşımları nasıldır? Z kuşağındaki bireyler bireysel veya toplumsal dini ritüellere ilişsin nasıl bir tutum sergilemektedir? Çalışmada bu problemler çerçevesinde $\mathrm{Z}$ kuşağının; hayatlarında dinin yeri ve anlamı, bireysel veya toplumsal dini ritüellere katılma durumları, bu tür uygulamaların onlara hissettirdikleri, dini konularda bilgilenmeye yönelik yaklaşımları ve bilgi edinme kanallarının tespit edilmesi amaçlanmıştır.

\section{Yöntem}

Z kuşağının dindarlık eğilimlerinin incelendiği bu çalışma nitel araştırma metodolojisinde uygun olarak iç içe geçmiş tek durum çalışması deseninde gerçekleştirilmiştir. Durum çalışması; güncel bir olguyu kendi gerçek yaşamı içerisinde çalışan, olgu ve içinde bulunduğu içerik arasındaki sınırların net olmadığı ve birden fazla veri kaynağının mevcut olduğu durumlarda kullanılan görgül bir araştırma yöntemi olarak tanımlanmaktadır (Yıldırım ve Şimşek, 2018, s. 290). İç içe geçmiş tek durum deseninde, tek bir durum içinde çoğu kez birden fazla alt tabaka veya birim olabilir (Yıldırım ve Şimşek, 2018, s. 291). Bu çalışmada Z kuşağının dindarlık eğilimleri araştırma konusu edildiğinden, dindarlık olgusu analiz edilecek durum olarak tasarlanmış, Z kuşağına göre dindarlığın analizi de incelenecek alt birimler olarak değerlendirilmiştir.

Araştırmada katılımcılar amaçlı örnekleme yöntemlerinden ölçüt örnekleme yöntemi ile belirlenmiştir (Büyüköztürk, Çakmak, Akgün, Karadeniz ve Demirel, 2019, s. 92-95). Bu kapsamda yapılan çalışmada Z kuşağından 10 kişi ile görüşmeler yapılmıştır. Ülkenin farklı şehirlerinde yaşayan, farklı meslek gruplarından, farklı eğitim düzeylerine sahip ve belirlenen kriterleri taşıyan $Z$ kuşağından kişilerle görüşülmüştür. Katılımcılar belirlenirken araştırmanın konu ve amacına uygun olması göz önüne alınarak $Z$ kuşağından kişilerin o kuşak hakkında kabul edilmiş özgürlüğüne düşkünlük, özgüveni yükseklik, teknoloji ile yakından ilgilenme, çabuk ve hızlı tüketme, adalet, eşitlik ve çevre konularında duyarlı olma (Özkoç ve Bayrakdaroğlu, 2017, s. 87) gibi özelliklere sahip olmaları dikkate alınmıştır. Katılımcılardan görüşmenin başında bu nitelikler bakımından kendilerini değerlendirmeleri istenmiş, belirlenen özelliklere sahip olduklarını onaylayan katılımcılar çalışmaya dâhil edilmiştir. 
Araştırma verilerinin toplanmasında, yarı yapılandırılmış görüşme tekniklerinden yararlanılmıştır (Büyüköztürk ve ark., 2019, s. 158). Bu yöntemi seçmemizde görüşme yönteminin Z kuşağının dindarlık eğilimleri ve kendi dindarlık algılamaları hakkında derinlemesine ve ilk elden bilgiler sunabilme potansiyeli etkili olmuştur (Yıldırım ve Şimşek, 2018, s. 158). Görüşme soruları dindarlığın farklı boyutları hakkında katılımcı yorumlarını öğrenmek amacıyla hazırlanmıştır. Bu kapsamda her bir soruda katılımcılara dindarlığın farklı boyutlarına yönelik sorular yöneltilmiştir. Araştırmacı tarafından hazırlanan sorular için daha sonra uzman görüşü alınarak bir görüşme formu oluşturulmuştur. Hazırlanan görüşme formu ile pilot görüşmeler sonrasında son hali verilerek asıl görüşmelere başlanmıştır. Verilerin analizinde nitel veri analizi tekniklerinden betimsel analiz tekniği kullanılmıştır (Yıldırım ve Şimşek, 2018, s. 239-240). Betimsel analiz tekniğinin seçilmesinde bu tekniğin dindarlığın boyutlarına göre temalandırma yapmamıza imkân tanıması ve bulguları daha sistemli sunmamızı sağlaması etkili olmuştur. Çalışmada elde edilen veriler Glock ve Stark’ın (Çelik, 2005, 75-90) ortaya koyduğu dindarlık modelinin unsurları çerçevesinde analiz edilmiştir.

\section{Bulgular}

\section{Katılımcıların Dinin İdeolojik Boyutuna İlişkin Algıları}

Araştırmada cevabını aradığımız temel problemlerden biri Z kuşağından kişilerin dindarlığa ilişkin algılarıdır. Kişilerin dindarlığa ilişkin algıları ile ilgili bulgular aşağıda gruplandırılarak sunulmuştur. Z kuşağından katılımcıların yaptıkları tanımlarda en çok işaret ettikleri konunun dinin kuralları olduğu görülmüştür. Bu doğrultuda bazı katılımcılar konu hakkında şu ifadeleri kullanmıştır:

İnandığı dini özgürlük ve kısıtlamaların içinde olan, inandığı dinin kurallarına göre yaşayıp hayatını inandığı dinin kitabına göre gerçekleştiren kişiye dindar insan derim. (K13)

Benim için dindarlık her şeyiyle dine yani anayasaya uyanlar, her şeyini dine adayanlar, tüm vaktini, parasını, kendisini, varıyla yoğuyla dini anlamaya çalışan, etrafındakilere bu dini yaymaya çalışan insanlardır. (K14)

İşte bu belirli yazılı şeyler çerçevesinde onlara uyan, onları yapan kişiler olarak tanımlarım. (K18)

Dine olan uygunluk, ona uygun yaşama, ona olan bağlılık; dindarlığı böyle tanımlarım. (K20)

Z kuşağından ifadeleri alıntılanan katılımcıların dindarlık tanımlarına bakıldığı zaman dindarlığın dini kuralları yerine getirmek şeklinde anlaşıldığı görülmektedir. Katılımcılar din ile ilgili tanımlarında da dinin kurallarına vurgu yapmışlardı. K12 kodlu katılımcının dindarlık tanımını yaparken insanları dindar veya dindar değil şeklinde damgalamanın doğru olmadığını ifade ederek dindarlığın bireyselliğine dikkat çektiği görülmektedir. Bunun yanında katılımcılar dindarlığı kişinin hayatını dine göre belirlemesi şeklinde tanımlayarak dinin etki boyutuna işaret etmektedir. Z kuşağından katılımcıların kimisi ise dindarlığı "İnsanın içindeki boşluğu kapatmak için kendince yaptığı şey.” şeklinde tanımlamış ve dinin insanın anlam arayışına bir cevap oluşuna değinmiştir. Kimisi de "Dindarlar bana göre dürüst olan, güvenir olan, ahlaklı ve ibadetlerine 
düşkün olan kişilerdir.” şeklinde tanımlayarak dinin ahlaki ve ibadet boyutunu öne çıkarmıştır. Katılımcıların dindarlığı tanımlarken dinin; teorik (bilgi), pratik (ibadet) ve ahlaki boyutlarına vurgu yaptıkları görülmüştür. Bununla beraber dinin kurallarını yerine getiren insanları dindar olarak tanımlayan katılımcıların, dindarlığı kusursuz bir şekilde dine bağlılık olarak anlamlandırdıkları gözlenmiştir.

Katılımcılar için inancın hayatlarına etkisi ve dinin hayatlarındaki yeri ile ilgili bulgular aşă̆ı̆da sunulmuştur. Z kuşağından bazı katılımcılar kendilerini dindar olarak gördüklerini şu şekilde ifade etmişlerdir:

..., şu an okuduğum yerde mesela on birlerin içinde tek cumaya gidenim. Şu an değerlendirmem belki yanlış olur, ortalamanın biraz üstünde kalıyor benim dindarlık eğilimim kendi çevremde. Çünkü baktığımız zaman benim yaşıtlarımın çoğu beş vakit namazı bile kılmıyor ki benim İslam'a bakış açımda genel olarak namaz aslında büyük bir kriter. İslam'ın da verdiği değer baktığımızda bu. ...Dindarlık olarak düşünürsek ortalamanın biraz üstünde diyebilirim. Nafile çok yapmıyor, farzları yerine getiriyorum. (K12)

Müslümanların yapması gereken şeylerden namazımı kılarım, Kur'an'ı okurum, abdestimi alırım, camiye giderim böyle yani dindarım. (K15)

İbadete önem veririm. Çoğu kişi yapamaz ama namaz kılarım, ahlaklıyım, güvenilirim. (K17)

K12 kodlu katılımcı kendi dindarlığını değerlendirirken hem kendi yaşıtları hem de arkadaş çevresi bağlamında konuya bakmaktadır. Bu noktada katılımcı dindarlık için namaz kılmanın önemli bir ölçüt olduğunu ifade ederek bu açıdan bakıldığı zaman kendi dindarlığının ortalamanın üstünde olduğunu belirtmiştir. Bununla beraber katılımcı namaz kılmamasına rağmen dindar gözüken insanların dini bir araç olarak kullandıklarını düşündüğünü ifade etmiştir. Katılımcının hem kendi dindarlığını hem başkalarının dindarlığını değerlendirirken ibadetleri yerine getirmeyi ölçüt olarak görmesi, dinin pratik (ibadet) yönünü önemsediğini göstermektedir. Bununla beraber katılımcının dinin ahlaki, öğreti, teorik gibi boyutlarını göz ardı ettiği anlaşılmaktadır. K15 ve K17 kodlu katılımcılar ise dinlerinin gereklerini yerine getirdikleri için kendilerini dindar olarak nitelendirdiklerini ifade etmişlerdir. İki katılımcının da dindarlık ile ilgili niteliklerinin ibadetler ile ilgili olması yine dinin pratik (ibadet) boyutuna işaret etmektedir. Bununla beraber K17 kodlu katılımcı bu kriterlere ahlaklı ve güvenilir olmayı da ekleyerek dinin ahlaki boyutunun dindarlık için bir gösterge olduğunu belirtmiştir. Bazı katılımcılar ise kendi dindarlıklarının orta düzeyde bir dindarlık olduğunu şu şekilde ifade etmişlerdir:

Benim kalbim temiz desem günah olur mu? Şimdi ben çok dindar bir insan değilim ama dini konularda hassaslıklara önem veriyorum. Mesela din lafı açıldığı zaman kendimize laf ettirmiyoruz ama çok da dindar değiliz. Yapılması gerekenlerin hepsini harfiyen yapmıyoruz. Belli başıı günler namazları kılarız ya da dediğim gibi belli başlı sünnetleri yerine getirmeye çalışırı. Su içerken, yemek yerken basit olanları yapıyorum ama çoğu aklımızdan çıkıyor. Yüzde otuz mu desem, kırk mı desem o civarda; dikkat ediyorum yani yüzde yüz dikkat eden zaten peygamber. (K14)

K14 kodlu katılımcı dini konularda hassas olmakla beraber dinin her kuralını harfiyen yerine getirmemesi sebebiyle kendisini dindar olarak tanımlayamayacağını ifade etmiştir. Katılımcının dindarlığı tam olarak dine 
bağlılık ve kurallarını yerine getirmek şeklinde anlamlandırdığı görülmüştür. Bazı katılımcılar da kendilerini dindar olarak görmediklerini şu şekilde ifade etmişlerdir:

On üzerinden değerlendirecek olursam dört derim veya üç, yorumlayacak olursam da pek bir yatkınlığım yok benim öyle dindarlığa. (K16)

Yani kitabımda yazanları yapmadığım için, kötü bir dindarlığa sahibim diye düşünüyorum. Kötü ya iyi bir dindar değilim. (K18)

Çok dindar olduğumu düşünmüyorum. Genel ibadetlerimi yerine getirmiyorum. Oruç tutuyorum ama en önemlisi tabii namaz. O yüzden kendimi dindar görmüyorum. (K19)

Kendimi çok dindar tanımlamam. Yani ben daha çok dindar değil de aslında inançlıyım yani böyle her şeye inanıyorum doğruluğuna yanlışlı̆ıına ama uygulamaya gelince bunu genelde hayata geçiremiyorum. O yüzden dindar olarak tanımlamam kendimi. (K20)

K18 kodlu katılımcı dini kuralları yerine getirmediğini ve bundan dolayı da kötü bir dindar olduğunu ifade etmiştir. Katılımcının dindarlığı dinin tek bir boyutu yani pratik (ibadet) boyutu üzerinden anlamlandırdığı görülmektedir. K19 kodlu katılımcı da genel olarak ibadetleri, özel olarak da namaz ibadetini, yerine getirmediği için kendini dindar olarak görmemektedir. K20 kodlu katılımcı ise inanç anlamında iyi olduğunu belirtmekle beraber inandığı şeyleri hayatına yansıtamaması sebebiyle kendisini dindar olarak tanımlayamayacağını belirtmiştir. Katılımcı dinin sadece inanç boyutunun yeterli olmayıp bunun yanında pratik (ibadet) boyutunun da olması gerektiğine işaret etmektedir. Üç katılımcının da dindarlığın ibadet boyutuna önem verdikleri görülmektedir. K13 kodlu katılımcı ise "Kendimi dindarlık açısından tanımlayabileceğimi düşünmüyorum. Hatta bir insanın kendini dindarlık açısından tanımlayabileceğine inanmıyorum. Bu tamamen Allah ile arasında olan bir şey. Yani tanımlayamam kendimi, ne derece dindar olup ne derece olmadığımı, bunu başka bir kişi de tanımlayamaz." şeklinde cevap vererek kendisini veya bir başkasını dindarlık durumuna göre tanımlayamayacağını, bunu sadece Allah'ın bileceğini ifade etmiştir.

Z kuşağından katılımcıların ifadeleri incelendiği zaman, katılımcıların kendi dindarlıklarını değerlendirirken, dinin gerektirdiği ibadetleri yerine getirme durumlarına göre yani dinin ibadet boyutuna göre bir karara vardıkları görülmüştür. Katılımcıların dinin ahlaki, teorik, sosyal gibi diğer boyutlarını geri planda bıraktıkları gözlenmiştir.

Katılımcıların inançlarını sorgulayıp sorgulamadıklarına ve inançlarından emin olup olmayışlarına ilişkin bulgular aşağıda gruplandırılarak sunulmuştur. Z kuşağından katılımcıların kendi inançlarından emin olma durumları ile ilgili bilgiler şu şekildedir:

Aslında sorgulamamız gerekiyor. Sorguladık da zaten ama ben felsefi baktığım zaman daha çok Gazali’nin fikirleri, akılla da duyularla da ne kadar sorgulasak ikisi de aldatıcı sonuçta. ... Bir de ufak çelişkiler görünüyor olsa da yani bunlar aklın aldatıcıllğından geldiğini düşünüyorum. Gerçek bilgiye ulaşabilmek için akıl yanıltıcıdır, duyular da yanıltıcıdır. Gerçek; kalpten, sezgilerden, imandan gelir. ... 
Dolayısıyla İslam'ın dediği gibi teslim olmamız gerekiyor. Bir yere kadar sorgulayıp, kudreti anlayıp ondan sonra teslim olmamız gerekiyor. (K12)

K12 kodlu katılımcı dini inancını sorgulamakla birlikte esasında dini konuda yüzde yüz eminliğin olamayacağını savunmaktadır. O bilimin de yanılabilir olması sebebiyle güvenilir bir kaynak olmadığına inanmaktadır. Katılımcı imanın sezgisel bir durum olduğunu ve dini inancının da ondan istediği gibi teslim olmak gerektiğini düşünmektedir.

Evet, Müslüman bir ailenin çocuğu olduğum için doğal olarak anne ve babanın dediklerine inanıyorsun. Bir zaman sonra yavaş yavaş olgunluğa erişince kendim karar vermeliyim diyorsun. Biraz araştırınca, evrenin kendi kendine olmadığına bir yaratıcının olduğuna inandım. Araştırmalar yaparak, meal okuyarak ve büyüklerime sorarak emin oldum... (K13)

K13 kodlu katılımcı ailesinden edindiği dini bilgileri sorgulayarak bu bilgilerin doğruluğundan emin olduğunu belirtmiştir. Katılımcı dini konularda bilgi edinmek istediği zaman Kur'an-1 Kerim'e başvurduğunu daha önce belirtmişti. Burada yaptığı sorgulamalarda mealler okuyarak, araştırmalar yaparak ve büyüklerine danışarak dini bilgilerinden emin olduğu görülmektedir. Bununla beraber katılımeı bu sorgulamayı karşı düşüncede olduğu için değil sadece inandığı şeyleri doğrulamak için yaptığını da eklemiştir. Katılımcının dini konularda doğru bilgi edinmeyi önemsediği görülmekle birlikte dini bilgileri sorgulamanın yanlış anlaşılmasından da çekindiği gözlenmiştir.

Tabi ki de sorguladım. ... Daha büyük şeyleri çok sorgulamadım. Zaten zaman geçtikçe Kur'an kursunda da camide de öğrendik doğru olduklarını. Yani ben onların yalancısıyım, yüzde yüz emin olamam. Onlar ne kadar eminse ben de eminim. (K14)

K14 kodlu katılımcı kendisine saçma gelen dini bilgileri öğretmenlerine veya imamlara sorduğunu belirtmekle birlikte büyük konuları sorgulamadığını da eklemiştir. Kur'an kurslarında, camilerde bu bilgilerinin doğru olduğunu öğrendiğini ifade etmiştir. Katılımcı kendi emin oluşunu ona bu bilgileri veren kişilerin eminliği ile ölçmektedir. Dini konularda bilgi noktasında katılımoının dışarıdan kendisine verilen bilgilerle sınırlı kaldığı ve bunlar üzerine bir araştırma yapmadığı görülmektedir.

K15 kodlu katılımcı da edindiği bilgileri hocalarına sorarak teyit ettirdiğini ifade etmiştir. Katılımcının sorgulama ihtiyacının hem dini konularda doğru bilgi edinmeyi önemsemesinden hem de sorumluluk duygusu ile insanlara doğru bilgi vermeyi önemsemesinden kaynaklandığı görülmektedir. K16 kodlu katılımcı da kendisine verilen her bilgiyi sorguladığını, bu sorgulamayı farklı kişilere sorarak yaptığını ve bilgilerini teyit ettiğini belirtmiştir. K17 kodlu katılımcı ise dini bilgileri edindiği kişiler güvendiği kişiler olduğu için sorgulamadan emin olduğunu ifade etmişsir.

Bazı şeyleri sorguluyorum mesela Kur'an'da yazmayan şeyleri genel anlamda her zaman sorguluyorum. Bazen de hatta ailemle de tartışıyoruz. Bu bilgilerin doğruluğundan gerçekten Kur'an'da ve mealde yazmadığı zaman emin olmuyorum. Hatta mealler okuduğum zaman da farklı meallerde farklı şeyler gördüğüm zaman ondan bile şüphe duyuyorum. Hangisi bana doğru geliyorsa; yani şöyle kendim için 
doğru tek, iyi bir insan olmak ya da kötü bir insan olmak. Ya hırsızlık yapmak yanlıştır, bu tarz şeylerden emin olabiliyorum. Ama onun dışında mesela kadınların sesini erkeklerin duymaması gerektiği gibi şeyleri sorgulamaya başliyorum. Onlardan emin olamıyorum bu şekilde. (K18)

K18 kodlu katılımcının da edineceği dini bilgilerin kaynağının Kur’an-1 Kerim olmasını önemsediği görülmektedir. Katılımcı dinin ahlaki gerekliliklerinin doğruluğundan emin olduğunu belirtirken kadınların sesinin erkeklere haram olması gibi dini bazı kurallardan emin olamadığını ifade etmiştir. Dinin ahlaki hükümlerinin doğruluğundan emin olan katılımcının, dininin bazı gereklerini anlamlandıramadığı için emin olmadığı görülmüştür. K19 kodlu katılımc1 ise edindiği bilgileri özel olarak sorgulamamakla birlikte lise döneminde doğru bilgilerle karşılaştıkça yanlış bilgilerin yerine doğru bilgileri koyduğunu belirtmiştir.

Bunu sorguladım galiba. Bu şeyi sorgulamıştım hatta oruçluyken diş firçalama mevzusu. Bunun doğruluğundan açıkçası hiç emin olamadım. Çünkü mesela annemlere göre bu yanlıştı. Yani onlar fırçalamıyorlar. Ama ben işte okul kitabında din kültürü kitaplarında firçalanabilir yazdığını gördüm, bir de diyanette de öyle yazıyordu firçalanabilir yazıyordu. (K20)

K20 kodlu katılımcının inancını değil de inancının getirdiği bazı davranışları sorguladığı görülmektedir. Katılımcı bu bilgileri doğru kaynaklardan araştırıp doğrusunu öğrenmesine rağmen çocuklukta öğrendiği bilgilerle farklılık gösterdiği için bu bilgilerden emin olamadığını söylemiştir.

Katılımcıların bazısı ailelerinden ve çevrelerinden edindikleri dini bilgileri sorguladıklarını ifade etmişlerdir. Katılımcılardan bazılarının bu sorgulamayı yaparken Kur'an-1 Kerim mealine başvurduğu, bazılarının ise çevrelerinden güvendikleri kişilere veya hocalarına danıştıkları görülmüştür. Katılımcılardan bazısının ise edindikleri dini bilgileri sorgulamadıkları görülmüştür.

\section{Dinin Pratik Boyutuna Yönelik Algıları}

Z kuşağından katılımcıların hayatlarında dinin etkili olup olmadığı ile ilgili bulgular aşağıda sunulmuştur:

K12 kodlu katılımcı, hayatında dinin etkisinin olduğunu ifade etmiştir. Özellikle namaz ibadetinin bu noktada belirleyici olduğunu düşünmektedir. Katılımcı, dininin kendisinden dengeli bir ibadet rutini istediğini belirtirken dinin sadece farzlarını yerine getirebilmesi sebebiyle etkisinin çok da fazla olmadığını ifade etmiştir. K13 kodlu katılımcı dininin hayatına etkilerinden bahsederken ilk olarak bu dünyada yalnız olmadığı (veya yalnız olmadığını bildiğini) ve bir amaç doğrultusunda yapıp ettiklerinin bir karşıllğ̆ olduğu düşüncesiyle hayatını buna göre şekillendirdiğini ifade etmiştir. Bu ifadesiyle katılımcı, dinin hem insanın varoluşsal sorularına cevap sağlamasından bahsetmekte hem de etki boyutuna işaret etmektedir. Bununla beraber katılımcı, hayatını bu doğrultuda şekillendirerek iyi bir insan olduğunu ifade etmiştir. Bu noktada yine dinin etki boyutu ile beraber dinin ahlaki boyutuna da işaret edildiğini görmekteyiz.

Her yerde var. Adım atarken, su içerken, yemek yerken, nefes alırken bile inancımızın bize etkisi var. Mesela ben ayakta su içerim ama eğer ki dinim aklıma geldiyse, inancım aklıma geldiyse çömelirim 
besmele çekerek su içerim. Tuvalete girerken, tuvaletten çıkarken adım şeklim bile ona göre değişiyor. Bir yere girip çıkarken artık eğer ki dikkat edersem, hatıllarsam hayatıma çok etki ediyor. Tabii hatırladığımız kadarıyla her yerde etkisi var. (K14)

K14 kodlu katılımcı hayatının her alanında dinin etkisinin olduğunu ifade etmiştir. Dininin hayatın her noktasına yönelik kurallarını hatırladığı ölçüde uyguladığını ve bu ölçüde hayatına etki ettiğini belirtmiştir. K15 kodlu katılımcı yapmış olduğu din tanımında da dininin hayatına olumlu katkılarının olduğunu ifade etmişti. Ayetlerde geçen Müslümanlarla ilgili ifadelerin ona huzur verdiği görülmektedir. K16 kodlu katılımcı, dinin hayatı üzerinde etkisinin olduğunu belirtirken dinin hayatta karşılaşılan zorluklara karşı insanı ayakta tutan bir etkisi olduğunu ifade etmektedir. Dinin bir başa çıkma yöntemi olduğu bilinmektedir ve katılımcının da karşılaşıtı̆ı olumsuz durumlara karşı inancı sayesinde daha ölçülü tepkiler verdiği anlaşılmaktadır. K17 kodlu katılımcı, dinindeki “Allah her an her şeyi görüp bilmektedir." inancının hayatını etkilediğini ve yönlendirdiğini ifade ederek dinin hayatında etkisinin büyük olduğunu ifade etmiştir.

Dinin hayatımdaki yeri şöyle, her genç insanın böyle olduğunu düşünüyorum ama genelde zora sıkıştığım zaman aklıma geliyor ya da belirli özel günlerde düşünüyorum. Onun dışında hayatıma çok da yerleştirdiğim bir konumda değil, önceliğim arasında dinim yok şu an. (K18)

K18 kodlu katılımcı bu kategori bağlamında hem kendini hem de kendi kuşağını eleştirmektedir. Dininin hayatında öncelikli bir yerinin olmadığını ifade ederek sadece zor anlarında ve dini özel günlerde aklına geldiğini ifade etmiştir. K19 kodlu katılımcı da dinin kurallarına vurgu yaparak bu kurallara uymaya çalışmasıyla dininin hayatı üzerinde etkisinin olduğunu ifade etmiştir. Bu konuda örneklendirmeyi, dinince yalan söylemenin günah olması sebebiyle yalan söylemediği şeklinde yaparak dinin ahlaki boyutuna işaret etmiştir.

Genelde benim dine en ihtiyaç duyduğum zaman, moralimin çok bozuk olduğu, çok zorlandığım zaman. Sabretmek için, güzel şeylerin olabileceğine inanmak için, bir umut olabilmesi için bu zamanlarda dine ihtiyaç duyarım. Yani benim hayatıma etkisi de mesela bir psikoloğun bir psikiyatristin insana etkisi neyse dinin de benim için etkisi odur. (K20)

K20 kodlu katılımcı da K18 kodlu katılımcı gibi dinin hayatındaki etkisini en çok sıkıntılı zamanlarda hissettiğini ve dine ihtiyacının en çok böyle zamanlarda olduğunu ifade etmiştir. İki katılımcının da dini, bir başa çıma yöntemi olarak değerlendirdikleri görülmektedir. Bununla beraber dini sadece ihtiyaç duyulan zamanlarda hatıllamak ve faydası üzerinden tanımlamak dinin araçsallaşmasına bir örnek olarak gözükmektedir. K21 kodlu katılımcı da dinin hayatın her yönüne etki etmesinden bahsetmekle birlikte kendisinin dini yaşama konusunda orta düzeyde olduğunu ifade etmiştir.

Katılımcıların dinin hayatları üzerindeki etkisini değerlendirmesinde, bazıları bu etkiyi hayatının her alanında hissettiğini ifade ederken bazısı da esasında dinin insan hayatının her alanına etkisi olmakla birlikte, dini vecibeleri eksiksiz yerine getirememeleri sebebiyle bu etkinin çok yoğun olmadığını ifade etmiştir. Bazı katılımcıların hayatında ise dinin sadece ihtiyaç duyulan zamanlarda etkili olduğu görülmüştür. 
Dindarlığın pratik boyutuna yönelik katılımcılardan aldığımız, günü planlarken dikkat ettikleri hususlar ve dini etkinliklerin günlük planlamalardaki etkisi ile ilgili cevaplarda günü planlamalarında dini faaliyetlerin etkisinin olmadığı görülmektedir. Katılımcılar günü planlarken başka etkinliklere göre planlama yaptıklarını belirtmişlerdir. Bazı katılımcılar ise günlük planlarının tamamını etkilememekle birlikte namaz gibi ibadetlere göre ayarlamalar yaptıklarını şöyle ifade etmişlerdir. K13 kodlu katılımcı Cuma namazı ve beş vakit namaz gibi ibadetlerin gün içerisinde çok büyük zaman almaması sebebiyle, ona göre özel bir planlama yapmadığını ifade etmiştir. Bunun yanında katılımcı, bayram namazları ve iftar zamanlarııın günü planlamasında etkili olduğunu belirtmiştir. K20 ve K21 kodlu katılımcılar da namaz dışında gün içerisinde dini etkinliklere göre planlama yapmadıklarını ifade etmişlerdir.

Yani bu -tabii özellikle namaz konusunda- bir yere giderken, abdestimi nerede alabilirim diye düşünüyorum. Ya da okula gideceğim zaman eğer bir işim çıacaksa ya da acelem varsa, abdestimi alıp çıkıyorum evden. $\mathrm{Bu}$ şekilde planlamalarımı yapıyorum. Onun dışında mesela bir il dışı seyahati yapacaksam bir tane seyahat setim var; seccade, kıble pusulası gerekirse diye yanıma alırım. (K12)

Çoğunlukla evet. Çünkü bu LGS süreci zor, bazen kendimi iyi hissetmek için ders çalışmadan önce okunacak bir dua okurum mesela. (K15)

Katılımcılardan bazısı ise yukarıdaki ifadelerini kullanarak dini etkinliklerin günü planlamalarında etkili olduğunu belirtmişlerdir. K12 kodlu katılımcı namazın dini için önemli bir gösterge olduğunu daha önceki cevaplarında belirtmişti. Burada da yapacağı gün içerisindeki planlamalarında dinin ve özellikle namazın önemli olduğu görülmektedir. K15 kodlu katılımcı da dinin gününü planlamasında etkili olduğunu belirtmekle birlikte zorlu sınav sürecinde kendisini iyi hissetmek için dua okuduğunu söylemiştir. Katılımcının hayatında dinin ruhsal anlamda rahatlatıcı bir etkisinin olduğu görülmektedir. Z kuşağından katılımcıların ifadeleri incelendiği zaman gün içerisinde yapılan faaliyetlerde dini etkinliklerin etkisinin çok sınırlı olduğu görülmüşsür. Dini etkinliklere göre planlama yapan katılımcıların da bu planlarında namaz ibadetinin etkili olduğu anlaşılmıştır.

Katılımcıların dinin pratik (ibadet) boyutuna ilişkin olarak hangi zamanlarda ibadethanelere gittikleri ile ilgili cevapları aşağıda gruplandırılarak sunulmuştur. Z kuşağından katılımcıların ibadethane rutinleri ile ilgili bilgiler şu şekildedir:

Salgından önce gidiyorduk. Yani kandillerde falan hep giderdik babamla birlikte. Cuma günleri zaten gidiyoruz farz olduğu için. Onun dişında kandillerde, işte Ramazanlarda teravihe giderdik. (K12)

Cuma erkekler için cemaatle namaz kılmak farz olduğu için gidiyorum. Normalde haftanın her günü camiye gidilebilir. Ben çok gidemiyorum boş olmama rağmen. $O$ anda çok gidemediğim için başka şekilde faaliyet göstermiyorum. (K13)

Katılımcıların ibadethanelere gitme durumlarının cemaatle kılınması zorunlu olan Cuma namazları ve dini özel günlerle sınırlı olduğu görülmektedir. K13 kodlu katılımcı ibadethanelere sadece Cuma namazı için gittiğini belirtirken ibadethanelere gitmek için normalde zamanı olmasına rağmen gitmediğini ifade etmiştir. K12 ve K14 kodlu katılımcılar da Cuma namazları, kandiller ve Ramazan ayında teravih namazları için camilere gittiklerini 
fakat günlük hayatta gitmediklerini ifade etmişlerdir. K17 kodlu katılımcı ise camilere gittiğini ve bazen de teravih namazına gittiğini belirtmiştir. Katılımcıların bazıları da ibadethanelere gitmediklerini şu şekilde ifade etmişlerdir:

Küçükken giderdim yani on beş yaşımdan sonra hiç gitmedim diyebilirim. (K18)

Yani çok istiyorum namaza başlamak falan ama yapmaya çalışıyorum bir şekilde olmuyor. İbadethanelere yani camilere gidemiyorum. (K19)

K18, K19 ve K21 kodlu katılımcılar ibadethanelere gitmediklerini ifade etmişlerdir. K19 kodlu katılımc1 esasında namaza başlamayı istediğini ifade etmekle birlikte şu anda günlük hayatında ibadet ve ibadethane rutininin olmadığını belirtmiştir. Katılımcılardan bazısı (K16) ve (K20) ise ibadethanelere nadiren gittiklerini ifade etmişlerdir. Katılımcı yorumlarına bakıldığı zaman $\mathrm{Z}$ kuşağından katılımcıların sürekli bir ibadethane rutinlerinin olmadığı görülmüştür. Katılımcılardan ibadethanelere gidenlerin Cuma namazları ve dini özel günlerle sınırlı olarak gittikleri gözlenmiştir.

Dinin sosyal (toplumsal) boyutuna ilişkin görüşlerini almak üzere yönelttiğimiz katılımcıların dini faaliyetlere katılma durumuna ilişkin cevaplar aşağıda gruplandırılarak sunulmuştur. Z kuşağından bazı katılımcılar konu hakkında düşüncelerini şu şekilde ifade etmiştir:

Çok fazla cemaat namazına gitmiyorum açıkçası yani sosyal hayat olarak. Onun dişında evde kendimiz yapıyoruz bazen. Annemle Ramazan'da mukabele yapıyorduk. Bunun dışında kandillerde ve teravihlerde falan gidiyorum sosyal olarak. (K12)

K12 kodlu katılımc1 toplu dini faaliyetlere genel olarak katılmamakla birlikte Ramazan ayında teravih namazlarına gittiğini, kandillerde camiye gittiğini ve evde annesiyle mukabele yaptığını belirtmiştir.

Sosyal hayatımda katılıyorum mesela biz ülkü ocağında Kur'an-1 Kerim tilavetleri yaparız, camileri temizliğe gideriz o tarz kendimiz faaliyetler oluştururuz. Şehitleri anmak için şehit mezarlarına gideriz, büyük alimlerin mezarlarına gideriz, mezarlarını temizler dua ederiz. Bu tarz faaliyetleri hem biz kendimiz yapıyoruz yapan varsa da biz de katılıyoruz. (K14)

K14 kodlu katılımcı toplu dini faaliyetlere katıldığını ifade etmiştir. Katılımcının Kuran-ı Kerim tilaveti dinlemek, cami temizliğine katılmak, şehit mezarları ziyaret etmek gibi toplu gerçekleştirilen dini faaliyetlere katılması dinin sosyal boyutunun katılımcının hayatında önemli bir yerinin olduğunu göstermektedir.

Katılımcılardan bazısı da toplu gerçekleștirilen dini faaliyetlere nadiren katıldıklarını şu şekilde ifade etmiştir:

Bazen hatim için cüz veriyorlar o şekilde nadiren katılıyorum. (K19)

Bunlara da çok katılmam. Çok nadir. (K20) 
Dini ibadetlere çok katılmıyoruz ama mesela Kur'an okunurken falan onları dinleyerek ya da eşlik ederek katılabiliyoruz. (K21)

Z kuşağından bazı katılımcılar ise toplu dini faaliyetlere kesinlikle katılmadıklarını şu şekilde ifade etmişlerdir:

Sosyal hayatımda dini faaliyetlere pek katılamıyorum. Çünkü şu anda hayatım çok yoğun bir şekilde ilerliyor pek vakit ayıramıyorum. Kendi kendime ibadetimi yerine getiriyorum. Kendi kendime yapmam gereken şeyleri yaptığımı düşünüyorum. İlerde inşallah katılırım. (K13)

K13 kodlu katılımcı bireysel olarak yerine getirebileceği ibadetleri yerine getirdiğini ifade etmiştir. Bununla beraber hayatındaki yoğunluk sebebiyle toplu dini faaliyetlere katılamadığını belirtmiştir.

Z kuşağından katılımcıların vermiş oldukları cevaplar incelendiği zaman çoğunun toplu dini ibadetlere katılmayı tercih etmediği görülmüştür. Bununla beraber bazı katılımcılar bazı toplu ibadetlere katılabildiklerini ifade ederken bazı katılımcılar da toplu dini faaliyetlere gönüllü olarak katıldıklarını ifade etmişlerdir.

\section{Katılımcıların Dinin Etki Boyutuna Yönelik Algıları}

Katılımcıların dinin günümüzdeki yeri ve etkisi ile ilgili cevapları aşağıda gruplandırılarak sunulmuştur. Z kuşağından bazı katılımcılar dinin günümüzde insanların hayatında daha geri planda olduğunu şu şekilde ifade etmiştir:

... Benim neslim özellikle dine karşı çok olumsuzlar, kandırıldıklarını düşünüyorlar, işte tamam diyorlar, işte İsa diyorlar, Muhammed diyorlar, İbrahim diyorlar, onlar diyorlar, iyi insanlarmış. İnsanları hizaya sokmaya çalışmışlar ama dinler gerçek değil diyorlar mesela. Gittikçe din devri kapanıyor gibi. (K14)

Katılımcılar dinin günümüzde daha az etkili olduğunu belirtmekle birlikte bunu farklı sebeplere dayandırmışlardır. K14 kodlu katılımcı günümüzde artık dinin daha az etkili olduğunu ifade ederken bunu teknolojinin getirdikleri ile açıklamıştır. Katılımcının dinin etkisinin azalmasını bilimsel gelişmeler ile açıklarken bir yandan da dinin bilinçli bir şekilde teknoloji aracılığı ile hayatlardan çıkarılmaya çalışıldığını ifade ettiği görülmüştür. K15 kodlu katılımcı da dinin etkisinin azalması durumunun teknolojinin gelişimi ile alakalı olabileceğini belirtmiştir. Bunun yanında katılımcı kendi kuşağının dine çok fazla önem vermediğini söyleyerek bu durumdan hoşnut olmadığını ifade etmiştir. K16 kodlu katılımcı dinin günümüzde geçmişe göre daha az etkili olduğu görüşüne katılmakla birlikte bir eleştiri de yaparak günümüzde dindar gözüken insanların da gösteriş için böyle gözüktüklerini belirtmiştir. K18 ve K20 kodlu katılımcılar ise durumu kendi yakın çevreleri üzerinden değerlendirerek dinin etkisinin azaldığı görüşüne katılmışlardır. Katılımcılar aile büyüklerinin hayatlarında dinin daha öncelikli olduğunu ifade ederken durumun kendileri için farklı olduğunu söylemişlerdir. K20 kodlu katılımcı dini kurallarının günümüzde daha esnetilebilir olduğuna dikkat çekmiştir. Bu görüşlerin aksine K17 kodlu katılımcı görüşlerini "Bence daha çok etkili. Mesela kadınlar camiye gider miydi, bilmiyorum ama bu zamanda gidiliyor. Bana göre bu zamanda daha çok insan ibadete yönelik ifadeler 
kullanılıyor." şeklinde ifade ederek dinin günümüzde daha fazla etkili olduğunu belirtmiştir. Katılımcı bu durumu kadınların camilere gidebilmesine ve insanların ibadetlere yönelik ifadeler kullanmasına bağlamıştır.

K12 kodlu katılımcı genel anlamda insanların hayatında dinin etkisinin azaldığını belirtmekle beraber İslam ve Yahudiliğin insanların hayatlarının her yerine nüfuz eden kurallar içermesi sebebiyle hayattaki yerinin çok fazla azalmadığını şu şekilde ifade etmiştir:

Bence azaldı bilimin biraz ilerlemesiyle falan ama İslam'ın aşırı azaldığını düşünmüyorum. Özellikle İslam ve Yahudilik, hayatın her alanında etkili olduğu için yani hayatın her yerinde ilmihal bilgileri hayatımızın her alanına dokunduğu için çok azalacağını düşünmüyorum. Sadece önemseyen kişi sayısı azalıyor ama önemseyen kişilerde hayattaki yeri değişmiyor genelde. Devletten falan çıkmasıyla şöyle belki de çağın gerektirdikleri buydu yani din bireyselleşiyor artık toplumdan ziyade bireylere indirgeniyor bireyci oluyor din. (K12)

Bunun yanı sıra katılımcı çağın bir gereği olarak insanların gitgide bireyselleşmesi sonucu dinin de daha bireysel yaşandığını ifade etmiştir. Katılımcının yorumuna göre din bireylerde değil toplumda etkisini kaybetmiştir. Son olarak K13 kodlu katılımcı da dinin etkisinin zamana göre değişmeyeceğini şu şekilde ifade etmiştir:

Katılmıyorum, dinin eskiye göre yeniye göre değiştiğine hiçbir şekilde. Sadece şu anda teknolojinin o vermiş olduğu görsellik ve yazısal şeylerden dolayı böyle düşünüldüğünü düşünüyorum. Gerçekten dindar olan insan böyle şeylerden kendini soyutlayabilir. O yüzden katılmıyorum böyle bir şey olduğuna.

Katılımcı dinin etkisinin az olduğu yönündeki görüşlerin özellikle böyle gösterilmek istendiğini ifade ederek gerçek dindarların çağın getirdiklerinden uzak kalabileceğini ifade etmektedir. Katılımcıların konu hakkındaki yorumları incelendiği zaman, bazısının dinin günümüzde etkisini yitirdiği yönündeki görüşlere katıldıkları görülmüştür. Katılımcılardan bazıları bu durumu bilimsel gelişmelere, teknolojinin ilerlemesine ve çağın gereklerine bağlamıştır. Bazı katılımcılar ise dinin etkisinin özellikle azaltılmaya çalışıldığını düşünmektedirler.

Din her dönemde çok hassas bir konu olarak insanların hayatında yer edinmiştir. Din insan hayatının her alanını kapsayan ve şekillendiren yönü sebebiyle her ortamda sık konuşulan bir konu olmuştur. Bu yönde katılımcılara dinin sosyal boyutu ile ilgili yöneltmiş olduğumuz, çevrelerindeki dini konularda konuşmayı tercih ettiği kişiler ve nedenleri hakkındaki bulgular aşağıda gruplandırılarak sunulmuştur.

Z kuşağından katılımcıların konu hakkında düşünceleri şu şekildedir:

Daha çok annemle konuşurum. Annemle boş zamanlarımızda kitap okuması falan da yaparız. Daha çok felsefi yapıyoruz o da öğrencilerden gelen garip sorulara yanıt verebilmek için falan daha çok İslam felsefesi, Din felsefesi bu tarz şeyler de yapıyoruz. Bunun dışında mezhepler tarihini konuşmayı da severim. Annemle konuşurum başka yok. (K12) 
Dini konuları babamla konuşuyorum. Babamın meali okumuş bitirmiş ve de bilgili bir insan olduğunu düşünüyorum. Yeri geldiğinde din kültürü hocalarıma birkaç ufak sorular soruyorum kafama takılan şeyleri. (K13)

Bizim akrabamız var Merve abla. O bu konularda çok bilgili. Genelde dinle ilgili merak ettiğim çoğu şeyi ben ona sorarım. Dinimle ilgili aklımda kalan çoğu soru var ve bazen bu soruları kendi kendime düşünürken kendimi kötü hissediyorum. Diyorum acaba yanlış bir şey mi düşünüyorum? Gidip ona soruyorum sonra o bana açıklıyor ve içim rahatlıyor. Çünkü çoğu insana göre dinle ilgili çok bilgili, gerçekten araştıran ve doğruluğunu öğrenmeden peşini bırakmayan bir insan. Bilgisinin çok fazla olduğunu düşündüğüm için ona güveniyorum. (K19)

Z kuşağından katılımcıların dini konularda genellikle aile veya yakın çevrelerinden kişilerle konuştukları görülmüştür. K12 kodlu katılımcı dini konularda annesiyle konuştuğunu, zaman zaman kitap okumaları yaptıkların ifade etmiş, felsefe ve mezhepler tarihi konularında konuşmaktan keyif aldığını belirtmiştir. K13 kodlu katılımcı da dini konularda babası ve hocalarıyla konuştuğunu ifade etmiştir. Katılımcı babası ile konuşmasının sebebini ise babasının meali bitirmiş bilgili bir insan olması şeklinde açıklamıştır. K14 kodlu katılımcının ise çevresindekilerle dini konularda konuşmaktan keyif aldığı görülmektedir. Katılımcının bunu dini bilgi edinmek için bir firsat olarak gördüğü anlaşılmaktadır. K15, K18 ve K19 kodlu katılımcılar aile ve yakın çevrelerinden bilgisine güvendikleri kişilerle konuştuklarını ifade etmişlerdir. K19 kodlu katılımcı zaman zaman dini konularda kafasının karışmasının kendisine kötü hissettirdiğini ifade ederken bu konuları konuştuktan sonra rahatladığııı ifade etmiştir. Bazı katılımcılar ise dini konuları konuştukları bir yakınlarının olmadığını ifade etmişlerdir. Z kuşağından katılımcıların verdikleri cevaplar incelendiği zaman dini konularda daha çok aileden veya yakın çevrelerinden bilgisine güvendikleri kişilerle konuştukları görülmüş̧ür.

Dinin insanların hayatlarının hemen hemen her alanında etkisinin olduğu bilinmektedir. Bu etkiyi arkadaş seçimi noktasında değerlendirmek üzere; Z kuşağından katılımcıların arkadaş seçiminde dindarlığın bir kriter olarak tercih edilip edilmediği ile ilgili cevapları aşağıda gruplandırılarak sunulmuştur. Z kuşağından bazı katılımcılar arkadaş seçimlerinde dindarlığın önemli olduğunu şu şekilde ifade etmişlerdir:

Evet etkiliyor. Ben dini olmayan insanla arkadaş olurum ama kardeş olmam. Çünkü dini bir konuda tartışma çıktığı zaman daha fazla zıtlaşmamak için. Hassas bir konu din. (K14)

İlk başta etkilemiyor ama sonrasında yani samimiyet kurmaya başladığımız zaman tabii ki yani görüşlerin düşüncelerin aynı olması etkiliyor. Ama ilk başta seçerken dindar olsun, şöyle olsun böyle olsun demiyorum. (K20)

K14 kodlu katılımcı inancı konusunda hassas olduğunu belirterek dindar olmayan bir kişiyle yakınlık kurmayacağını belirtmiştir. K20 kodlu katılımcı da benzer şekilde ilk başta bunun önemli bir etken olmadığını fakat yakınlık kurdukça görüşlerin benzer olmasının önemli olduğunu belirtmiştir. K19 kodlu katılımcı da "İbadetini yapıyor mu yapmıyor mu diye bakmıyorum ama eğer gerçekten dinden çok uzak ve yani kötü huylara sahipse tabii uzak duruyorum." ifadelerini kullanarak genel anlamda dindarlığın çok etkili olmamakla birlikte 
dine çok uzak biriyle de arkadaşlık kurmayı tercih etmeyeceğini belirtmiştir. Katılımcının arkadaş seçiminde ibadetleri yerine getirmesine dikkat etmemekle beraber ahlaki değerlerin bu seçiminde etkili olduğu görülmektedir. Z kuş̧ă̆ından katılımcıların verdikleri cevaplara göre bazısının arkadaş seçiminde dindarlığın hiçbir etkisinin olmadığı görülürken, bazısının da bu konuyu önemsedikleri ve bu doğrultuda seçim yaptıkları görülmüştür.

\section{Dinin Duygu Boyutuna İlişskin Algıları}

Dini faaliyetlerin $Z$ kuşağı gençlerine hissettirdikleri ile ilgili cevaplar aşağıda gruplandırılarak sunulmuştur. Bu hususta bazı katılımcılar dini faaliyetleri yerine getirmenin kendilerine huzur verdiğini ifade etmişlerdir:

Namaz kılarken kendimi daha rahat daha huzurlu hissediyorum çünkü o benim yaratıcım olduğunu düşündüğüm. Onunla olan iletişimim olduğunu düşünerek kendimi daha güvende, daha huzurlu hissediyorum ve yalnız hissetmiyorum. Zekât verirken insanlara yardım etmenin güzel bir şey olduğunu düşünüyorum, oruç tutarken insanın aç kalabilmesini ve o süreçte neler olabileceğini veya onların halinden anlamış olmak beni mutlu ediyor bundan dolayı huzurlu oluyorum. (K13)

Oruç tutmak mesela nefsimize hâkim olmak amacıyla bazı açlık, yoksulluk çeken insanları anlamamızı sağlar; empati sağlar. Oruç tutmak bana mutlu hissettirir, namaz kılmak güvende hissettirir, Allah'ın bir nevi daveti gibi. (K17)

Sadaka vermek mesela küçük çocuğa sadaka verdiğinde, çocuk mutlu olduğunda sen de mutlu olursun. Aynı şekilde oruç tuttuğunda, namaz kıldığında, zekât verdiğinde Allah'ın rızasını kazandığın için mutlu olursun. (K21)

Katılımcıların yerine getirdikleri ibadetler sonrası kendilerini huzurlu hissettikleri görülmektedir. K13 kodlu katılımcı namaz ibadetinin kendisini güvende hissettirdiğini ifade ederek bu şekilde yaratıcısı ile iletişim kurduğunu belirtmiştir. Katılımcı bunun yanında oruç tutmak ve insanlara yardım etmek gibi ibadetlerin de huzur verdiğini eklemiştir. K15 kodlu katılımeı ise dini inancının ve ibadetlerinin kendisini olumsuzluklardan koruduğuna inanmaktadır. Katılımcının daha önceki cevapları da göz önünde bulundurulduğunda dini, hayatı kolaylaştıran, ona ayrıcalıklar tanıyan ve olumsuz durumlardan koruyan bir araç olarak gördüğü gözlenmiştir.

K16 kodlu katılımcı da dini ibadetleri yerine getirdiği zaman dünyadan kısa bir süre de olsa uzaklaşmanın kendisine iyi geldiğini ifade etmiştir. K17 kodlu katılımcı oruç ibadetine dikkat çekerek bu ibadet sayesinde açlık çeken insanlarla empati kurma imkanına eriştiğine değinmiştir. K19 ve K21 kodlu katılımcılar ise ibadetlerle Allah'ın istediği davranışları yerine getirmiş olmanın huzur verici olduğundan bahsetmişlerdir.

Bazı katılımcılar ise dini faaliyetleri yerine getirdikleri zaman bir yükten veya bir sorumluluktan kurtulduklarını düşünerek iyi hissettiklerini şu şekilde ifade etmişlerdir:

Farz ibadetlerde ödevimi yapmış, teslim etmiş gibi hissediyorum. Diğer nafile ibadetlerde mesela kandil gibi özel bir gün varsa yapmadığım zaman bir vicdan azabı oluyor. Sen bugünü boş geçirdin, bugün bir şeyler yapabilirdin şeklinde ama yaptığımda mutlu oluyorum tabii. (K12) 
K12 ve K14 kodlu katılımcılar ibadetleri yerine getirdikten sonra bir görevi yerine getirmiş olmanın verdiği huzurlu hissi yaşadıklarını ifade etmişlerdir. K12 kodlu katılımcı bu durumu farz ibadetleri yerine getirdikten sonra yaşadığını ifade ederken, K14 kodlu katılımcı ise bu durumu özellikle namaz kılarken yaşadığını belirtmiştir. Bununla beraber K12 kodlu katılımcı nafile ibadetleri yerine getirmediği zaman kendini vicdanen rahatsız hissettiğini ifade etmiştir. K14 kodlu katılımcının ve diğer katılımcıların da zekât ve sadaka ibadetine ayrı bir değer verdiği görülmektedir. Katılımcıların çoğu bu ibadetleri yerine getirdikleri zaman huzurlu hissettiklerini ifade etmiştir. K18 kodlu katılımcı da oruç, zekât ve sadaka ibadetlerinin kendisini huzurlu hissettirmekle beraber namaz gibi zorunlulukları yerine getirmekte zorlandığını şu şekilde ifade etmiştir:

Belirli bir zorunluluğu yaparken çok zorlanıyorum. O, üzerime dayatıldığı zaman çok zorlanıyorum, namaz kılmak gibi. Belli bir alışkanlık da kazanmadım şu zamana kadar ama oruç tutmak daha iyi gelir. Zekât veya sadaka vermek de gerçekten mutlu hissettiriyor, hakkım geçtiği zaman sadaka veriyorum.

Z kuşağından katılımcıların cevapları incelendiği zaman, katılımcıların çoğunun yerine getirdikleri ibadetlerin kendilerini iyi hissettirdiği ve onlarda olumlu duygular uyandırdığı görülmüsşür. Bununla beraber bazı katılımcıların namaz gibi günlük yerine getirilmesi zorunlu olan ibadetleri yerine getirmekle üzerlerinden bir sorumluluğun kalktığını düşündükleri anlaşılmaktadır. Ayrıca katılımcıların tamamının zekât ve sadaka gibi insanlara yardım etme faaliyetlerine ayrı bir önem verdikleri anlaşılmıştır.

\section{Dinin Bilgi Boyutuna İlişkin Katılımeı İfadeleri}

Katılımcıların dinin bilgi boyutu bağlamında dini bilgiler elde etmek amacıyla çeşitli kaynaklardan yararlanıp yararlanmadıkları ile ilgili bulgular aşağıda sunulmuştur. Katılımcıların tamamı dini bilgi edinmeyi önemsediğini ifade etmekle beraber, her biri bu durumu farklı şekillerde açıklamışlardır. Bu sebeple katılımcıların yorumları ayrı ayrı ele alınacaktır.

Evet, gerekli ilmihal bilgilerine falan evde Ömer Nasuhi Bilmen'in ilmihali var, ona bakarız annemle. İlmihal dışındaki akaid bilgilerine falan da araştırarak yani kitaplardan okuyorum. Genelde vaaz çok dinlemedim ama kitap okudum. Siyer kitapları, akaid kitapları falan okudum. (K12)

Evet mesela dincimiz okulda kıssa anlatırken ben onu iyice dinlerim, mutlu olurum, huzur verir. İlmihallerdeki bilgileri okurum, dualara bakarım bana iyi gelir. (K15)

Katılımcılar dini konularda bilgi edinmek istedikleri zaman çeşitli dini kitaplara başvurduklarını ifade etmişlerdir. K12 kodlu katılımcı farklı dini konularda çeşitli kaynaklara başvurduğunu belirtmiştir. Katılımcı; ilmihaller, akaid kitapları ve siyer kitaplarını zamanında çok fazla okuduğunu belirtmiştir. K15 kodlu katılımcı da ilmihal kitaplarından bilgi edindiğini ifade ederken kıssaları dinlemenin de kendisini mutlu hissettirdiğini ifade etmiştir. K17 kodlu katılımcı da ihtiyaç duyduğu zamanlarda ilmihallere başvurduğunu ifade etmiştir. Katılımcılardan bazısı ise dini konularda bilgi edinmek istediği zaman internet üzerinden araştırma yaptığını şu şekilde ifade etmiştir: 
Evet, önemsiyorum dini kaynaklara ulaşacak kadar çalışkan bir insan değilim. Elimizde telefon var direkt oradan yazarım. Sadece bir siteye değil de birkaç siteye bakarım doğrulamak için. Vaaz dinlemek de işte Cumadan Cumaya. Önemsiyorum çünkü ileride bir günah işlerim ya ben bunun günah olmadığını bilmiyorsam Allah bana sorar neden araştırmadın diye. Çünkü elimin altında firsat var. (K14)

K14, K18 ve K20 kodlu katılımc1lar dini konularda internet üzerinden sorularına cevap aradıklarını belirtmişlerdir. K14 kodlu katılımcının dini konuları araştırmasındaki ana etkenin, dini konularda bilgi edinmeyi bir sorumluluk olarak anlaması olduğu gözlenmiş̧tir. Z kuşağından bazı katılımcılar ise konu hakkında şu ifadeleri kullanmıştır:

Vaaz dinliyorum, meal elimden geldiğince okumaya çalışıyorum ama meal okuduğumda da onu bir anda anlayamadığım için onu daha farklı şekilde araştırmaya çalışıyorum. Bu konuda bilgili kişilere soruyorum. Hiçbir şekilde internetten bakmıyorum yanlış bilgi edineceğim diye. (K13)

K13 kodlu katılımcı vaaz dinlemenin yanında dini konularda bilgi edineceği kaynağı İslam'ın temel kaynağı Kur'an-1 Kerim ile sınırlandırmıştır. Katılımcının yanlış bilgi edinmemek için internetten uzak durması ve dininin temel kaynağına yönelmesi onun dini konularda doğru bilgiye ulaşma konusunda hassas olduğunu göstermektedir.

Genelde bazı günler ezbere bilmediğim sureleri ezberlemeye çalışıyorum veya Kur'an okuyorum ama vaaz dinlemiyorum. Surelerin anlamını ve nerede indirildiğini bilince kendimi iyi hissediyorum, sorumsuz hissetmiyorum kendimi ama tabii bazı sorumluluklarımı yerine getirmediğim için rahatsız oluyorum. (K19)

K19 kodlu katılımcı da K13 kodlu katılımcı gibi dini bilgi edinme noktasında Kur'an-1 Kerim'e yöneldiğini ve indirilen ayetleri daha iyi anlamaya çalışmanın kendisini iyi hissettirdiğini ifade etmiştir. Katılımcıların ifadeleri incelendiği zaman genellikle dini konularda bilgi edinmeyi önemsedikleri görülmekle birlikte yöneldikleri kaynaklar farklılık göstermektedir. Katılımcılar dini konularda Kur’an-1 Kerim, İlmihaller, Akaid kitapları, Siyer kitapları ve internet gibi kaynaklardan bilgi edindiklerini ifade ederken çoğunun vaaz dinlemediği görülmüştür. Z kuşağından katılımcıların dinin bilgi (teorik) boyutunu önemsedikleri görülmektedir.

Daha çok anneme soruyorum. $\mathrm{O}$ da din kültürü öğretmeni zaten ama biz çıkamadıysak işin içinden ilmihale bakarız. Onun dışında internete de bakıyorum ama internette o kadar çok yorum farklılığı var ki bir ayetten birisi başka bir şey çıkarırken birisi başka bir şey çıkarabiliyor. Onun için ya da ayetler speküle edilebiliyor internet çok güvenilir gelmiyor. Dediğim gibi kitaptan bakarız o da olmazsa annem bilen birisine sormaya çalı̧̧ıor. (K12)

Katılımcıların ilk yöneldikleri kaynakların dini kitaplar olduğu görülmektedir. İkinci bir kaynak olarak ise internete yöneldikleri anlaşılmaktadır. K12 kodlu katılımcı annesinin Din Kültürü ve Ahlak Bilgisi Öğretmeni olması sebebiyle sorularını ona sorduğunu belirtmekle birlikte, dini kaynaklarda ihtiyaç duyduğu bilgilere ulaşamadığı takdirde internete başvurduğunu fakat internetteki bilgilere mesafeli olduğunu belirtmiştir. K15, K16, K17 ve K19 kodlu katılımcılar da ilk olarak dini kitaplara bakıp sonrasında internet üzerinden araştırma 
yaptıklarını belirtmişlerdir. K19 kodlu katılımcı internet üzerinden edindiği bilgileri daha sonra bir bilene sorarak teyit ettirmektedir. Bunun yanı sıra K20 kodlu katılımcı "İnternet, Youtube sadece. Çok da bir kaynağa başvurmuyorum." ifadelerini kullanarak sadece internet üzerinden araştırma yaptığını belirtmiştir

Z kuşağından bazı katılımcılar da şu ifadeleri kullanmıştır: "Kur'an mealine erişiyorum başka hiçbir yerden hiçbir kaynağa başvurmamayı tercih ediyorum. Çünkü internet ortamında bazı hadislerin veya kitaplarda bile bazı hadislerin yanlış olduğunu düşünüyorum.” (K13) Katılımcıların dini konularda bilgi edinme noktasında temkinli oldukları görülmektedir. K14 kodlu katılımcı ise dini konularda bilgi edinmek istediği zaman çevresinde bilgisine güvendiği kişilere danıştığını ifade etmiştir:

Tanıdığım bazı cemaatlerden ağabeyler var ya onları ararım sorarım ya da internetten araştırma yaparım. O da olmazsa kendi arkadaşlarımdan İmam Hatip mezunu bir iki yakın arkadaşım onları arar onlara sorarım. Çevremde bu din konusunda benden daha iyi bildiğini düşündüğüm insanlara danışırım. Daha da bulamazsam hani daha fazla kurcalamam herhalde. ( K14)

Z kuşağından katılımcıların dini bilgi edinme amacıyla farklı kaynaklara başvurdukları görülmüştür. Katılımcılar Kur'an-1 Kerim, ilmihaller, dini kitaplar, internet gibi kaynaklara başvurmanın yanı sıra çevrelerinden bilgisine güvendikleri kişilere de başvurduklarını ifade etmişlerdir.

Katılımcıların internet ve sosyal medyada edindikleri bilgilerin doğruluğu hakkındaki cevapları aşağıda gruplandırılarak sunulmuştur. Z kuşağından bazı katılımcılar konu hakkında şu ifadeleri kullanmıştır:

İnternette kimin yazdığı belli değil. Kime göre, neye göre yazdığı belli değil, onun için çok doğru bulmuyorum sosyal medya ve internet bilgilerini. (K12)

Kesinlikle düşünmüyorum. Hatta internette gördüğüm dinle ilgili şeylerin yüzde doksanına inanmamaya çalışıyorum. Eğer daha önce ona yakın bir şey duyduysam olabilir diyorum. Bazı siteler var gerçekten doğru bilgi veren. Onlara inanabilirim birkaç kez doğruluğunu kanıtlamışsam, böyle güvenimi almışsa inanırım. (K14)

Yani çoğunu düşünmüyorum çünkü dediğim gibi merak ettiklerime baktığımda başka bilen bir kişiye sorma ihtiyacı duyuyorum çünü bazıları inandırıcı gelmiyor veya inandırıcı gelse bile doğru değiller. (K19)

Bunu düşünmüyorum çünkü herkes bir şeyler yazıyor. Bunun tek doğru olduğu yer Kur’an diye düşünüyorum. (K21)

Katılımcıların internet üzerinden dini konular ile ilgili karşılaştıkları bilgilere güvenmedikleri görülmektedir. K12 kodlu katılımcı internetteki bilgilerin kaynağının belli olmaması sebebiyle güvenmediğini belirtmiştir. K13 kodlu katılımcı ise karşılaştı̆̆ bilgilerin doğruluğunu tespit edebilecek bilgiye sahip olmaması sebebiyle internet üzerinden araştırma yapmadığını ifade etmiştir. K14 kodlu katılımcının internetteki her bilgiye mesafeli yaklaştığı görülmektedir. K21 kodlu katılımcı da internete güvenmemekle birlikte bu konuda güveneceği tek 
kaynağın Kur'an-1 Kerim olduğunu belirtmiş̧tir. Katılımcıların dini konularda bilgi edinecekleri kaynakları seçerken dikkatli oldukları anlaşılmaktadır. K15 ve K19 kodlu katılımcılar internette karşılaşıkları dini bilgileri teyit ettirmek amacıyla güvendikleri kişilere sorduklarını ifade etmişlerdir. K20 kodlu katılımcı ise internette veya sosyal medyada edindiği bilgilere inandığını şöyle ifade etmiştir:

Düşünüyorum ya, ben çok çabuk inanırım böyle şeylere. O yüzden genelde düşünüyorum. Yani bilmiyorum birkaç sayfaya giriyorsun mesela hepsinde aynı şey yazıyorsa zaten ben hiçbir şey bilmiyormuş gibi hissederim. O yüzden çok çabuk inanırım.

Z kuşağından katılımcıların internet ve sosyal medyadan edindikleri bilgilere güvenmedikleri görülmektedir. Katılımcıların hangi dini kaynaklara yöneldikleri sorusunda; bazıları internet üzerinden araştırma yaptıklarını ifade ederken, bu soruya internetteki bilgilere güvenmedikleri şeklindeki cevapları dikkat çekicidir. Katılımcıların dini bilgileri araştıracakları kaynaklar konusunda internetteki bilgilere mesafeli olmakla birlikte internet üzerinden güvendikleri sayfaları tercih ettikleri ve bazısının da bu bilgileri başka kaynaklarla teyit ettikleri gözlenmiştir.

\section{Sonuç ve Tartışma}

Kuşak Teorisi merkezinde $\mathrm{Z}$ kuşağının dindarlık eğilimlerinin özelliklerini ortaya koymak amacıyla gerçekleştirdiğimiz bu araştırma sonucunda şu sonuçlar elde edilmiş̧ir:

Çalışmada Z kuşağından çoğu katılımcının, dindarlığı "dinin kurallarını yerine getiren kişi” ifadesini kullanarak ibadet boyutunda sınırlandırdıkları görülmüştür. Buna karşın katılımcıların dinin ibadet boyutunun yanında etki, bilgi, ahlak gibi boyutlarına ilişkin göndermeler yaptığı da tespit edilmiştir. Bu durum, çalışma grubunda yer alan katılımcıların dindarlıkta ibadete ağırlık vermekle birlikte çok boyutlu ya da kapsayıcı bir dindarlık anlayışına sahip oldukları şeklinde değerlendirilebilir. Bunun yanında bazı katılımcıların da yerine getiremedikleri ibadetler dolayısıyla dindarlık düzeylerini yeterli görmedikleri anlaşılmışır. Katılımcıların önemli bir kısmının ise kendilerini dindar olarak değerlendirmedikleri sonucuna ulaşılmıştır. Z kuşağından katılımcıların bazısının ailelerinden edindikleri dini bilgileri sorguladıkları bazısının olduğu gibi kabul ettiği, sorgulayanların ise bu sorgulamayı Kur'an-1 Kerim'den araştırarak veya güvendikleri birine sorarak yaptıkları görülmüştür.

Dinin etki boyutuyla ilgili olarak; $Z$ kuşağından katılımcılarda dinin hayat üzerindeki etkisi daha çok ibadetleri yerine getirip getirmeme üzerinden açıklanmıştır. Z kuşağından katılımcıların günlük planlamalarında dini faaliyetlerin etkisinin çok sınırlı olduğu; bazı katılımcıların ise dinin etkisini namaz ibadeti ile sınırlandırdığı görülmüştür. Buradan hareketle $\mathrm{Z}$ kuşağından katılımcıların dinin hayata etkisini daha dar bir çerçevede anladıkları, dolayısıyla dinin etkisini indirgemeci bir bakışla yorumladıkları söylenebilir. Kuşkusuz bu durum küreselleşme ve toplumsal değişme olguları ile ilgili olarak değerlendirilmelidir. Bu bulgular Şen (2019, s. 150) tarafından gerçekleştirilen çalışmanın bulgularıyla benzerlik göstermektedir. Yapılan bu çalışma sonucunda lise çağındaki gençlerin dini inançlarının hayatlarına etkisinin az olduğu sonucuna ulaşılmıştır. 
Dinin pratik boyutuyla ilgili olarak; Z kuşağından katılımcıların düzenli bir ibadethaneye gitme rutinlerinin olmadığı, ibadethanelere gittiğgini ifade eden katılımcıların ise bu durumu Cuma namazı, bayram namazı, teravih namazları ve özel dini günlerle sınırlı tuttukları görülmüştür. Elde edilen bu bulgular, Şen (2019, s. 150) tarafından gerçekleştirilen çalışmanın bulguları ile benzerlik göstermektedir. Yapılan bu çalışmada, lise öğrencilerinin anne-babalarına göre daha az ibadet ettikleri belirlenmiştir. Aynı şekilde Çalışkan (2021, s. 153) tarafından gerçekleştirilen çalışmada, $Z$ kuşağından gençlerin dinin ibadet boyutuna daha az önem atfettikleri ve onların çoğunun hiçbir toplu dini faaliyete katılmadıkları görülmüştür. Sonuç olarak Z kuşağından katılımcıların genel olarak toplu dini faaliyetlere katılmayı tercih etmedikleri ve ibadetlerini tek başlarına yerine getirmeyi tercih ettikleri anlaşılmıştır. Buradan hareketle, katılımcıların daha çok dinin bireysel yönüne vurgu yaparak sosyal boyutunu dışarıda bıraktıkları söylenebilir.

Dinin duygu boyutuna ilişkin olarak; Z kuşağından katılımcıların dini faaliyetler sonrası olumlu duygular hissettikleri sonucuna ulaşılmıştır. Katıılımcıların olumlu duyguları en çok namaz, oruç ve sadaka ibadetlerinde hissettikleri görülmüştür. Dinin sosyal boyutuna ilişkin olarak; Z kuşağından katılımcıların birkaçı dışında arkadaş seçiminde kişilerin dindarlık düzeyleri veya dininin etkisinin olmadığı görülmüştür. Diğer taraftan Z kuşağından katılımcıların çoğunlukla dinin sosyal hayattaki kapsama alanının daraldığını düşündükleri anlaşılmıştır. Bununla birlikte Z kuşağından katılımcılar söz konusu durumu bilimsel gelişmelere ve çağın gereklerine bağlamışlardır. Katılımcıların arkadaş seçiminde dini özelliklerin değil ahlaki özelliklerin önemli olduğunu ifade etmesi ahlakın dinin dışında bağımsız bir olgu gibi anlaşıldığı şeklinde yorumlanabilir.

Dinin bilgi boyutuna ilişkin olarak; Z kuşağından katılımcıların dini konularda bilgi edinmeyi önemsedikleri; vaaz dinlemeyi tercih etmedikleri ve Kur'an-1 Kerim, ilmihal kitapları, internet siteleri gibi kaynaklardan bilgi edindikleri görülmüştür. Diğer taraftan katılımcıların dini konularda bilgi edinirken, kaynak konusunda hassas davrandıkları tespit edilmiştir. Konu ile ilgili elde edilen bulgular, Öztürk (2021, s. 51) tarafından yapılan çalışmada elde edilen bulgular ile benzerlik göstermektedir. Çalışmaya göre, 12. sınıf öğrencilerinin sosyal medya üzerinden elde ettikleri bilgilere şüphe ile bakmakla birlikte, sağlam bir kaynaktan geldiğine inandıkları bilgilere güvendikleri görülmüştür. Aydın (2020, s. 74) tarafından gerçekleştirilen çalışmada da dini bilgi edinme noktasında benzer bulgular elde edilmiştir. Çalışma sonucunda, Z kuşağından gençlerin dini bilgi noktasında kendilerini ailelerinden daha iyi bir noktada görmekle birlikte, dinin pratik boyutu hakkında kendilerini daha zayıf gördükleri tespit edilmiştir. Z kuşağından katılımcıların ailelerinden veya çevrelerinden güvendikleri ve rahat konuşabildikleri kişilerle dini konularda konuştukları anlaşılmıştır. $Z$ kuşağından katılımcıların internet ve sosyal medyadaki dini bilgiler konusunda temkinli oldukları görülmüştür. Fakat Z kuşağından katılımcıların çoğunun güvendikleri sitelerden araştırma yaptıkları tespit edilmiştir.

Sonuç olarak, Z kuşağından katılımcıların genel anlamda benzer dindarlık algılamaları ve eğilimlerine sahip oldukları; dinin bilgi, duygu ve sosyal boyutlarına ilişkin algılamalarının birbirleri ile benzerlik gösterdiği; buna karşın dinin etki ve pratik boyutlarında farklı anlayışlar geliştirdikleri anlaşılmıştır. Çalışmanın bu sonuçlarından hareketle şu öneriler sunulabilir: Çeşitli medya platformlarında sunulan din eğitimi faaliyetlerinde dinin sadece ibadet boyutundan ibaret olmadığı, onun duygu, etki, sosyal ve bilgi gibi başka boyutlarının da olduğu hususu güçlü bir şekilde ifade edilmeli, toplumun bütüncül bir din anlayışı geliştirebilmesine yardımcı olunmalıdır. Gerek yaygın gerekse örgün din eğitimi hizmetlerinde din ve ahlak arasındaki ilişkilendirmeler daha güçlü ifade 
edilmeli, toplumda din ve ahlak birlikteliği konusunda farkındalık oluşturulmalıdır. Kuşaklar arasındaki dini anlama ve yorumlamadaki farklılıkların nedenleri, bunların göstergeleri ve dindarlık anlayışları konusunun daha iyi anlaşılabilmesi için nitel ve nicel farklı çalışmalar gerçekleştirilmelidir.

\section{Kaynakça}

Akyüz, İ. (Aralık 2014). Türkiye'de gençlik, din ve değerler konusunda yapılan ampirik araştırmaların yöntem ve içerik analizi. Sakarya Üniversitesi Ilahiyat Fakültesi Dergisi, 16 / 30, 183-202. https://doi.org/10.17335/sakaifd.219877

Arslan, A. \& Staub, S. (2015). Kuşak teorisi ve içgirişimcilik üzerine bir araştırma. KAÜ İ̈BF Dergisi, 6/11, 1-5.

Aydın, N. (2020). Z kuşağı ve din (Yüksek lisans tezi, Marmara Üniversitesi, Sosyal Bilimler Enstitüsü, İstanbul). https://tez.yok.gov.tr/UlusalTezMerkezi/ adresinden edinilmiştir.

Batson, C. D.; Schoenrade, P.; Ventis, W. L. (2017). Din ve birey. (A. Kuşat ve A. Taştan, Çev.), Kayseri: Kimlik Yay.

Bilge, E. Z. \& Kula, M. N. (2020). Liseli gençlerin dindarlık eğilimi ve iyilik algısı arasındaki ilişki. Eskişehir Osmangazi Üniversitesi Sosyal Bilimler Dergisi, 21/1, 215-240. https://doi.org/10.17494/ogusbd.763650

Büyüköztürk, Ş.; Çakmak Kılıç, E.; Akgün, E.; Karadeniz, Ş. \& Demirel, F. (2019). Eğitimde bilimsel araştırma yöntemleri. Ankara: Pegem Akademi.

Çalışkan, S. (2021). Z kuşă̆ında deizm algısı ve deistliğe yönelten sosyolojik faktörler (Yüksek lisans tezi, Onsekiz Mart Üniversitesi, Lisansüstü Eğitim Enstitüsü, Çanakkale). https://tez.yok.gov.tr/UlusalTezMerkezi/ adresinden edinilmiştir.

Çelik, C. (2005). Dindarlık Tipolojilerine Metodolojik Bir Yaklaşım, İslâmiyat, 8/2, 71- 90.

Çetin, R. (2019). Ortaöğretim Öğrencilerinin Dindarlı Düzeyleri ve Ahlaki Çözülme Eğilimleri (Yüksek Lisans Tezi, Necmettin Erbakan Üniversitesi, Sosyal Bilimler Enstitüsü, Konya). https://tez.yok.gov.tr/UlusalTezMerkezi/ adresinden edinilmiştir.

Die 18. Shell Jugendstudie (2019). (Erişim Tarihi: 20 Temmuz 2021). https://www.shell.de/about-us/shell-youthstudy/_jcr_content/par/toptasks.stream/1570708341213/4a002dff58a7a9540cb9e83ee0a37a0ed8a0fd55/shellyouth-study-summary-2019-de.pdf

Gürsu, O. \& Önce Özokudan, F. S. (2019). Ergenlerde dindarlık, narsizm ve özgüven. Türk Akademik Araştırmalar Dergisi, 4/4, 439-454.

İnce, F. (2018). Kuşaklar arası etkin iletişim ve davranış. Konya: Eğitim Yayınevi. 
Karslı, N. (2021). Üniversite öğrencilerinde manevi-insani değerler ve dindarlık ilişkisi. Ondokuz Mayıs Üniversitesi Ilahiyat Fakültesi Dergisi, 50, 143-174. https://doi.org/10.17120/omuifd.891300.

Kaya, F. Ş. (2018). Üniversite gençliğinin öz-duyarlılık, değer yönelimleri ve dindarlık eğilimleri (devlet ve vakıf üniversiteleri karşılaştırması). Sosyoloji Araştırmaları Dergisi, 21/2, 144-179.

Kuran, E. (2020). Bir kuşă̆ı anlamak. 4. Baskı. İstanbul: Mundi Yayınları.

Kuran, E. (2020). Telgraftan tablete. 12. Bask1. İstanbul: Destek Yayınlar1.

Mannheim, K. (1952). The problem of generations, in P. Kecskemeti (Ed.), Essays on the sociology of knowledge (pp. 276-320). London: Routledge and Kegan Paul.

Öztürk, F. D. (2021). Sosyal medyanın 12. sınıf ögrencilerin dini bilgileri üzerindeki etkileri (Yüksek Lisans Tezi, Eskişehir Osmangazi Üniversitesi, Sosyal Bilimler Enstitüsü, Eskişehir). https://tez.yok.gov.tr/UlusalTezMerkezi/ adresinden edinilmiştir.

Sarığlu, E. B. (2018). Y’leri anla değiştirme. İstanbul: Humanist Kitap Yayıncılık.

Strauss, W. \& Howe, N. (1991). Generations: The history of America's future, 1584 to 2069, New York: William Morrow and Company.

Şen, S. (2019). Sekülerleşme: Lise gençliği üzerine sosyolojik bir araştırma (Yüksek Lisans Tezi, Marmara Üniversitesi, Sosyal Bilimler Enstitüsü, İstanbul). https://tez.yok.gov.tr/UlusalTezMerkezi/ adresinden edinilmiştir.

Topçuoğlu, A. \&Aksan, G. (2019). Üniversite gençliğinin değerleri: 20 yıl sonra ne değişti?. OPUS Uluslararası Toplum Araştırmaları Dergisi, 11/18, 2241-2274. https://doi.org/ 10.26466/opus.571209.

Türk, A. (2013). Y kuşağı. İstanbul: Kafekültür Yayıncılık.

Twenge, J. M. (2018). i-Nesli. İstanbul: Kaknüs Yayınları.

Yıldırım, S. \& Gürsu, O. (2021). Yetişkinlerde dindarlık ve psikolojik dayanıklılık ilişkisi. Türk Akademik Araştırmalar Dergisi 6/1, 28-49.

Yıldırım, A. \& Şimşek H. (2018). Sosyal bilimlerde nitel araştırma yöntemleri. 11. baskı. Ankara: Seçkin Yayınları.

Yıldırım, A. (1999). Nitel araştırma yöntemlerinin temel özellikleri ve eğitim araştırmalarındaki yeri ve önemi, Eğitim ve Bilim Dergisi, 23, 1-10. 